\title{
Fetomaternal outcome in sickle cell disease in a tertiary care centre
}

\author{
Rahi S. Modi*, Srushti S. Patel, Dipti A. Modi, Heena Talesara
}

Department of Obstetrics and Gynecology, Medical College Baroda, Vadodara, Gujarat, India

Received: 03 December 2020

Accepted: 05 January 2021

\section{*Correspondence:}

Dr. Rahi S. Modi,

E-mail: rahimodi07@gmail.com

Copyright: () the author(s), publisher and licensee Medip Academy. This is an open-access article distributed under the terms of the Creative Commons Attribution Non-Commercial License, which permits unrestricted non-commercial use, distribution, and reproduction in any medium, provided the original work is properly cited.

\section{ABSTRACT}

Background: Sickle cell disease is a hereditary haematological disorder prevalent in tribal regions of India. Sickle cell disease can increase complications during pregnancy and in turn negatively influence pregnancy outcomes. This study reports the analysis of tribal maternal admissions in the tertiary centre S.S.G. Hospital, Baroda, Gujarat. Hence this study was conducted to assess complications in pregnancy and maternal and perinatal outcome among women with Sickle cell disease.

Methods: It was a retrospective observational study including all pregnant women with sickle cell disease after 20 weeks of gestation who delivered at S.S.G. Hospital, Baroda from August 2019 to August 2020.

Results: There were 43 antenatal women with Sickle cell disease during the study period. There was increased risk of obstetric complications like gestational hypertension (11.62\%), preeclampsia (9.3\%), eclampsia (6.97\%), HELLP syndrome $(4.65 \%)$, intrauterine growth retardation $(23.25 \%)$, and oligohydramnios $(11.62 \%)$. Medical complications observed were mainly anaemia $(53.48 \%)$, vaso-occlusive crisis $(18.16 \%)$, acute chest syndrome $(4.65 \%)$ and infections like urinary tract infection $(6.97 \%)$ and pneumonia $(4.65 \%)$. The incidence of low birth weight babies (56.94\%), low APGAR score (11.62\%) and neonatal ICU admissions (23.25\%) was high. $6.5 \%$ cases of maternal mortality and $4.65 \%$ cases of perinatal mortality was observed.

Conclusions: Pregnancy in Sickle cell disease is associated with an increased maternal morbidity and high perinatal mortality due to obstetric and medical complications.

Keywords: Maternal morbidity, Maternal mortality, Perinatal outcome, Perinatal mortality, Sickle cell disease, Vasoocclusive crisis

\section{INTRODUCTION}

Sickle cell disease is the most common inherited disorder worldwide with varying clinical severity and serious complications. ${ }^{1}$ Globally, India accounts for $14.5 \%$ of the total new-borns with Sickle cell disease. ${ }^{2}$ The sickle cell gene has been shown to be prevalent among three groups in India - the scheduled tribes, the scheduled castes and other backward classes. ${ }^{3}$

In Gujarat, the Dhodia, Dubla, Gamit, and Naika tribes have a high prevalence of Sickle cell disease.Some tribal groups in south Gujarat like Chaudhary, Gamit, Rohit,
Vasava and Kukana have shown both a high prevalence of $\mathrm{HbS}$ as well as $\beta$-thalassaemia trait. ${ }^{4}$

The maternal complications of pregnancies complicated by sickle cell disease are anemia, infection, vaso occlusive crisis, preeclampsia, preterm labour and increased risk of caesarean section.

Fetal problems affecting perinatal outcome are intrauterine growth restriction, premature birth, abnormal fetal heart rate, and intrauterine fetal death. ${ }^{5}$ High maternal and fetal mortality are seen in pregnant mothers with sickle cell disease. ${ }^{6}$ 
Many population groups have been screened in India and the sickle cell gene has been shown to be prevalent among three socio-economically disadvantaged ethnic groups - the scheduled tribes, the scheduled castes and other backward classes. ${ }^{7}$

This study was conducted to assess complications in pregnancy and maternal and perinatal outcome among women with Sickle cell disease.

\section{METHODS}

It was a retrospective observational study including all pregnant women with sickle cell disease after 20 weeks of gestation who delivered at S.S.G. Hospital, Baroda Medical College, Baroda from August 2019 to August 2020 .

The information taken from medical records for each woman were age, parity, genotype of sickle cell disease and whether belonging to tribal population or not. Maternal morbidity was assessed by analyzing both medical and obstetric complications (anemia, infectious morbidity, sickle cell crises, IUGR, gestational hypertension, eclampsia, abruption, and preterm labour). Anemia among pregnant women was taken as hemoglobin level less than $11 \mathrm{~g} / \mathrm{dl}$, severe anemia defined as hemoglobin level less than $7 \mathrm{~g} / \mathrm{dl}$ and the need for blood transfusion was analyzed.

The details of labour as gestational age at delivery, whether induced or spontaneous, and mode of delivery were collected. The perinatal outcome was measured by analyzing the APGAR score, birth weight, need for NICU admission and mortality.

\section{RESULTS}

There were 7920 deliveries in the S.S.G. Hospital from August 2019 to August 2020 of which 43 (0.54\%) women were with sickle cell disease during the study period.

Table 1: Age wise distribution.

\begin{tabular}{|lll|}
\hline Age group & Number & Percentage \\
\hline <20 years & 2 & 4.65 \\
\hline 20-30 years & 34 & 79.16 \\
\hline >30 years & 7 & 16.66 \\
\hline Total & 43 & 100 \\
\hline
\end{tabular}

The above table shows, age wise distribution of the patients from 19 to 39 years with a mean age of 26.6 years. Majority (63.89\%) of the women with Sickle cell disease were multiparous while $36.11 \%$ were nulliparous. The above table shows that the most significant obstetric complication noted during pregnancy in cases with sickle cell disease was hypertension (pre-eclampsia and gestational hypertension) and its complications like eclampsia and HELLP syndrome. Antepartum eclampsia occurred in 2 cases, while intrapartum and postpartum eclampsia both occurred in one case. Pre eclampsia occurred in $4(9.30 \%)$ cases while HELLP syndrome occurred in $2(4.65 \%)$ cases.

Table 2: Obstetric complications.

\begin{tabular}{|lll|}
\hline Complications & Number & Percentage \\
\hline Previous perinatal loss & 5 & 11.62 \\
\hline Previous miscarriage & 3 & 6.97 \\
\hline Pre-eclampsia & 4 & 9.30 \\
\hline Gestational hypertension & 5 & 11.62 \\
\hline Eclampsia & 3 & 6.97 \\
\hline HELLP syndrome & 2 & 4.65 \\
\hline $\begin{array}{l}\text { Gestational Diabetes } \\
\text { Mellitus }\end{array}$ & 2 & 4.65 \\
\hline IUGR & 10 & 23.25 \\
\hline Oligohydramnios & 5 & 11.62 \\
\hline Preterm labour pain & 2 & 4.65 \\
\hline Abruption & 2 & 4.65 \\
\hline
\end{tabular}

Intrauterine growth restriction (IUGR) was observed in $10(23.25 \%)$ cases. Ultrasonography finding of oligohydramnios was observed in 5 cases (11.62\%), while abruption placenta was seen in $2(4.65 \%)$ cases. There were no cases of premature rupture of membrane, placenta previa and abnormal flow in umbilical and middle cerebral artery Doppler. Gestational diabetes mellitus was observed in $2(4.65 \%)$ cases, preterm labour pain was observed in $2(4.65 \%)$ cases. Previous perinatal loss was seen in $5(11.62 \%)$ cases and previous miscarriage was seen in $3(6.97 \%)$ case.

Table 3: Sickle cell disease related complications.

\begin{tabular}{|lll|}
\hline Complications & Number & Percentage \\
\hline Anemia & 23 & 53.48 \\
\hline Vaso-occlusive crisis & 8 & 18.60 \\
\hline Acute chest syndrome & 2 & 4.65 \\
\hline Bone crisis & 4 & 9.30 \\
\hline Haemolytic crisis & 1 & 2.32 \\
\hline Urinary tract infection & 3 & 6.97 \\
\hline Pneumonia & 2 & 4.65 \\
\hline Total & 43 & 100 \\
\hline
\end{tabular}

The above Table shows, the commonest medical complication observed in these women during pregnancy was anemia defined as hemoglobin level less than 11 gm\%. Total $23(53.48 \%)$ of Sickle cell disease women had anemia of which 20 had mild to moderate anemia $(\mathrm{Hb}=7-10.9 \mathrm{gm} \%)$, while 3 had severe anemia $(\mathrm{Hb}<7$ gm \%). One woman with severe anemia was admitted with cardiac failure. Antenatal transfusions for correction of anemia was required in $23(52.77 \%)$ cases. Vasoocclusive crisis occurred in $8(18.60 \%)$ cases of which 2 cases had acute chest syndrome. There were 4 cases with bone crisis, 1 case with haemolytic crisis. Jaundice which 
is a usual accompaniment of Sickle cell disease was present in 10 cases. Total 3 cases $(6.97 \%)$ had urinary tract infection and $2(4.65 \%)$ cases had pneumonia. Other infectious pathology noted were periodontal abscess in one case and cellulitis of both lower limbs in another during antenatal period.

Labour was induced in 21 (29.67\%) of the Sickle cell disease cases.15 cases were induced for Intrauterine growth restriction (IUGR) and hypertensive complications. Sickle cell crisis with worsening maternal condition was the indication for induction of labour in 2 cases. 2 cases each were induced for intrauterine fetal demise and postdatism respectively.

Table 4: Gestational age at time of delivery and mode of delivery.

\begin{tabular}{|lll|}
\hline Gestational age & $\begin{array}{l}\text { Vaginal } \\
\text { delivery }\end{array}$ & $\begin{array}{l}\text { Caesarean } \\
\text { section }\end{array}$ \\
\hline Preterm $(<\mathbf{3 7}$ weeks) & 6 & 2 \\
\hline Term $(\mathbf{3 7 - 4 0}$ weeks) & 20 & 12 \\
\hline Past date $(>\mathbf{4 0}$ weeks) & 2 & 1 \\
\hline Total & 28 & 15 \\
\hline
\end{tabular}

Above table shows, majority of the cases $32(74.41 \%)$ in the study population had term delivery. 8 (18.06\%) cases were preterm delivery, of which 5 were induced and 3 were elective preterm caesarean section for obstetric indications. Total $28(65.11 \%)$ cases delivered vaginally, while $15(34.88 \%)$ cases underwent caesarean section.

One case who was induced for HELLP syndrome underwent preterm emergency LSCS for failed induction. $6(8.33 \%)$ cases went into preterm labour. Of those who delivered past date, two cases went into labour spontaneously; one case (previous Caesarean Section) underwent elective caesarean section.

Table 5: Indications for caesarean section.

\begin{tabular}{|lll|}
\hline $\begin{array}{l}\text { Indication of caesarean } \\
\text { section }\end{array}$ & Number & Percentage \\
\hline Previous caesarean section & 7 & 46.6 \\
\hline $\begin{array}{l}\text { IUGR with abnormal } \\
\text { Doppler }\end{array}$ & 2 & 13.3 \\
\hline Fetal distress & 2 & 13.3 \\
\hline $\begin{array}{l}\text { Failed induction for } \\
\text { HELLP/preeclampsia/ } \\
\text { IUGR }\end{array}$ & 3 & 20.0 \\
\hline Intrapartum eclampsia & 1 & 6.66 \\
\hline Total & 15 & 100 \\
\hline
\end{tabular}

Above Table shows indications of caesarean section. Among 15 (34.88\%) cases, most common indication for caesarean section was previous caesarean section 7 (46.6\%), followed by fetal distress 2 (13.3\%) and Doppler abnormalities associated with intrauterine growth restriction $2(13.3 \%)$. Elective primary caesarean section was done in 3 cases with severe Intrauterine growth restriction (IUGR) showing absent or reversal of flow in umbilical artery Doppler study.

Atonic PPH occurred in one case $(1.39 \%)$ with sickle cell disease, which was controlled by medical management and blood transfusion. None of the women had thromboembolism in the antepartum or postpartum period.

Table 6: Baby Birth weight wise distribution.

\begin{tabular}{|lll|}
\hline Birth weight & Number & Percentage \\
\hline $\mathbf{2} . \mathbf{5} \mathbf{~ k g}$ & 18 & 43.06 \\
\hline $\mathbf{1 . 5 - 2 . 5 ~ k g}$ & 19 & 44.44 \\
\hline$<\mathbf{1 . 5} \mathbf{~ k g}$ & 6 & 13.95 \\
\hline
\end{tabular}

Above Table shows birth weight wise distribution. Intrauterine growth restriction (IUGR) and prematurity accounts for $25(58.93 \%)$ low birth weight babies. There were $6(13.95 \%)$ cases with very low birth weight of less than $1.5 \mathrm{~kg}$. Mean birth weight was $2.1 \mathrm{~kg}$

Table 7: Perinatal outcome.

\begin{tabular}{|lll|}
\hline Perinatal complication & Number & Percentage \\
\hline Prematurity & 6 & 13.95 \\
\hline Low birth weight & 20 & 46.51 \\
\hline Five-minute Apgar score $<7$ & 5 & 11.62 \\
\hline Neonatal ICU Admission & 10 & 23.25 \\
\hline Perinatal morality & 2 & 4.65 \\
\hline
\end{tabular}

The above Table shows perinatal outcome in sickle cell disease cases. Among 43 women, 41 (95.83\%) cases had live births, 1 case had intrauterine fetal demise and one case had still birth. Low Apgar score was detected in 5 (11.62\%) of live born babies.

Due to prematurity, low birth weight and respiratory distress, $10(23.25 \%)$ babies needed admission to the neonatal ICU for further monitoring and care. There were two neonatal deaths due to perinatal birth asphyxia. The perinatal mortality rate was $4.65 \%$.

\section{DISCUSSION}

Pregnancy in sickle cell disease can be complicated as both prospective mother and neonate are at increased risk of adverse outcomes. The physiological changes of pregnancy like increased metabolic demand, increased blood viscosity and hyper-coagulability gets aggravated in Sickle cell disease patients leading to increased incidence of complications like vaso-occlusive crisis, acute chest syndrome, osteonecrosis, hepatic necrosis, leg ulcers, and thromboembolic events. Vaso-occlusion also occurs in placenta leading to villous fibrosis, necrosis, and infarction thereby causing impaired uteroplacental circulation, which leads to chronic fetal hypoxia and adverse fetal outcomes. ${ }^{6}$ With more awareness about the 
disease and with better treatment options and facilities, more females are reaching the child bearing age. This has led to an increase in the number of pregnant Sickle cell disease patients (mostly tribal).

In this study, sickle cell disease was found in only $0.15 \%$ of cases, this is comparable to study done by Ugboma et al in which rate was $0.2 \% .^{6}$ The low incidence may be because only the tribal antenatal women with complications are reporting to the institution and those with undiagnosed Sickle cell disease especially the ones with sickle cell trait (without any symptoms) deliver in their nearby health centres. Pregnancy in sickle cell women is at high risk for maternal and fetal complications than in general population. ${ }^{8,9}$ In present study, Eclampsia was seen in 6.97 cases .

Wilson et al studied that Eclampsia which is a life threatening complication of preeclampsia was reported to be 10 times high in HbSS (Sickle cell disease) women. ${ }^{10,11}$ In this study, Intrauterine growth restriction was seen in $23.25 \%$ cases, is comparable to study done by Fatema et al in which rate was $20.1 \% .^{12}$

In the present study, $52.77 \%$ of sickle cell deliveries required blood transfusion which was similar to $52.7 \%$ transfusions as reported by Desai et al and $32 \%$ transfusion as reported by $\mathrm{Yu}$ et al. ${ }^{13,14}$

Pregnancy has been shown to exacerbate sickle cell crises. In this study, about $18.6 \%$ of vaso occlusive crisis and $4.65 \%$ of acute chest syndrome cases were observed, this is comparable to study done by Pinto et al in which $61.7 \%$ of vaso-occlusive crisis cases and $29.4 \%$ of acute chest syndrome cases. ${ }^{9}$

Infective complications observed in this study were mainly urinary tract infections $(6.97 \%)$ and pneumonia(4.65\%), this is comparable to study done by $\mathrm{Yu}$ et al in which combined incidence of UTI, lobar pneumonia and osteomyelitis was at $19 \%$ and in study done by John et al incidence was $82.5 \%$ which was very high. Infections was the cause of maternal mortality in $82 \%$ of sickle cell disease women in Muganyizi et al Tanzania. ${ }^{14,15,16}$ In our study, incidence of preterm birth was $18.06 \%$, this is comparable to study done by Desai et al and Ugobama et al, the incidence of preterm birth was as high as $44-45 \% .{ }^{13,6}$

Sickle cell disease in pregnancy has been associated with low birth weight, in our study it was $56.94 \%$, was observed in about $50 \%$ pregnancies by Ugboma et al and $43 \%$ cases by Desai et al. ${ }^{6,13}$ Factors responsible for this may be lower gestational age at delivery, maternal anemia, preeclampsia and intrauterine growth restriction.

Low Apgar score of $11 \%$ by Silva et al, $34.5 \%$ by Muganyizi et al and $50 \%$ by Acharya et al has been reported in babies born to Sickle cell disease mothers, while we had $11.62 \%$ babies with low Apgar score.
Because of prematurity, low birth weight and perinatal asphyxia due to IUGR, there was a high rate of neonatal ICU admissions. ${ }^{9,10,16,17}$

Despite many life-threatening complications, there were total $3(6.9 \%)$ maternal mortality in present study. This may be due to the improvement in the primary health care facilities and early reference of the Sickle cell disease cases from the remote tribal areas to our institution.

In our study, perinatal mortality $(4.65 \%)$ was primarily due to growth restriction. But, few previous studies have shown no increase in the perinatal mortality. ${ }^{7,13}$

\section{CONCLUSION}

Pregnancy in sickle cell disease is associated with an increased maternal morbidity and high perinatal mortality due to obstetric and medical complications. As most of the study population was identified to belong to the scheduled tribe population, active screening programmes need to be undertaken in the public health sector to identify women with sickle cell disease. Also, measures should be taken to give better care for them through improved preconception awareness and counselling about the disease, early and better antenatal care, prompt identification and treatment of complications and early referral to tertiary care facilities.

\section{ACKNOWLEDGMENTS}

Authors would like to express gratitude to Dr. Dipti A. Modi (Associate professor) of department of Obstetrics and Gynecology, Medical College Baroda, S. S. G Hospital, for her encouragement, valuable suggestions, constant support, all the ways and teaching me to strive for perfection. They also acknowledge their gratitude to their co-residents and all the patients and department of Obstetrics and Gynecology, who have cooperated for the study.

\section{Funding: No funding sources \\ Conflict of interest: None declared \\ Ethical approval: Not required}

\section{REFERENCES}

1. Rees DC, Williams TN, Gladwin MT. Sickle-cell disease. Lancet. 2010;376:2018-49.

2. Piel FB, Hay SI, Gupta S, Weatherall DJ, Williams TN. Global burden of sickle cell anaemia in children under five, 2010-2050: modelling based on demographics, excess mortality, and interventions. PLoS Medicine. 2013;10(7):22-9.

3. Colah RB, Mukherjee MB, Martin S, Ghosh K. Sickle cell disease in tribal populations in India. Indian J Med Res. 2015;141:121-7.

4. Bhukhanvala D, Gupte S, Patel A, Shah A, Sorathiya S. Prevalence and hematological profile of $\beta$ thalassemia and sickle cell anemia in four 
communities of Surat city. Indian J Human Genetics. 2012;18(2):167-71

5. Sparkenbaugh E, Pawlinski R. Interplay between coagulation and vascular inflammation in sickle cell disease. British J Haematol. 2013;162:3-14.

6. Ugboma H, George I. Sickle cell disease in pregnancy: maternal and fetal outcome in Port Harcourt, Nigeria. British J Medicine Medical Res. 2015;7(1):40-4.

7. Elenga N, Adeline A, Balcaen J, Vaz T, Calvez M, Terraz A, et al. Pregnancy in sickle cell disease is a very high-risk situation: an observational study. Obstet Gynecol Int. 2016;2016.

8. Oteng NE, Meeks D, Seed PT, Webster L, Howard J, Doyle $\mathrm{P}$, et al. Adverse maternal and perinatal outcomes in pregnant women with sickle cell disease: systematic review and meta-analysis. Blood. 2015;125(21):3316-25.

9. Silva-Pinto AC, Ladeira SOD, Brunetta DM, Santis GC, Angulo IL, Covas DT. Sickle cell disease and pregnancy: analysis of 34 patients followed at the regional blood center of ribeirão preto, Brazil. Revista Brasileira de Hematologia e Hemoterapia. 2014;36(5):329-33.

10. Wilson NO, Ceesay FK, Hibbert JM, Driss A, Obed SA, Adjei AA, et al. Pregnancy outcomes among patients with sickle cell disease at Korle-Bu Teaching Hospital, Accra, Ghana: retrospective cohort study. Am J Tropical Med Hygiene. 2012;86(6):936-42.

11. Ngô C, Kayem G, Habibi A, Benachi A, Goffinet F, Galactéros F, et al. Pregnancy in sickle cell disease: Maternal and fetal outcomes in a population receiving prophylactic partial exchange transfusions.
European J Obst Gynecol Reproductive Biol. 2010;152(2):138-42.

12. Jama FE, Gasem T, Burshaid S, Rahman J, Suleiman SA, Rahman MS. Pregnancy outcome in patients with homozygous sickle cell disease in a university hospital, Eastern Saudi Arabia. Arch Gynecol Obst. 2009;280(5):793-7.

13. Desai G, Anand A, Shah P, Shah S, Dave K, Bhatt $\mathrm{H}$, et al. Sickle cell disease and pregnancy outcomes: a study of the community-based hospital in a tribal block of Gujarat, India. J Health Population Nutrition. 2017;36(1):3.

14. Yu CKH, Stasiowska E, Stephens A, Awogbade M, Davies A. Outcome of pregnancy in sickle cell disease patients attending a combined obstetric and haematology clinic. J Obst Gynaecol. 2009;29(6):512-6.

15. Orazulike FN, Ijeoma FC. Feto-maternal outcome in patients with sickle cell anaemia at the University of Port Harcourt Teaching Hospital, Port Harcourt, Nigeria: a ten year retrospective review. Int J Obstet Gynecol. 2015;3:54-8.

16. Muganyizi PS, Kidanto $H$. Sickle cell disease in pregnancy: trend and pregnancy outcomes at a tertiary hospital in Tanzania. PLoS ONE. 2013;8(2):34-8.

17. Acharya N, Kriplani A, Hariharan C. Study of perinatal outcome in pregnancy with sickle cell disease. Int J Biol Med Res. 2013;4(2):3185-8.

Cite this article as: Modi RS, Patel SS, Modi DA, Talesara H. Fetomaternal outcome in sickle cell disease in a tertiary care centre. Int J Reprod Contracept Obstet Gynecol 2021;10:619-23. 